\title{
SELAHATTIN EYYUBÎ'NIN NESEBI
}

\author{
ISMAİL YAKIT ${ }^{*}$
}

Uzun zamandır tartışlan ve polemik konusu yapılan bir konu var. O da Haçlılara kan kusturan ve onları Kudüs'ten söküp çıaran ve Eyyubî Devleti'nin ünlü sultanı Selahattin Eyyubî'dir. Peki Selahattin'in nesi tartışllyyor? Tek kelimeyle kimliği ve nesebi ve buna dayanarak kurduğu devletin bir Türk Devleti olup olmadığı tartışma konusu yapılıyor. Yaygın rivayetler onun baba tarafını Kürt olarak gösterirken, birkaç kaynak da Arap olduğunu söyleyerek ona şecere isnat etmektedir. Birçok kaynak da onun Türk kökenli olduğunu belirtmektedir. Onun kimliğini ve nesebini tayin etmede kaynaklar ne derece güvenli, dönemindeki tarihi ve kültürel veriler ne derece incelendi? Selahattin kendini ne olarak hissediyor? Bunların belgeleri var mıdır? İşte cevabını aramamız gereken sorular bu ve bu nevi sorulardır.

\section{Selahattin Eyyubî Kimdir?}

Mısır, Suriye, Fırat havzası (Irak) ve Yemen bölgelerinin hükümdarı, Eyyubî Devletinin kurucusu, Hıristiyanların 88 yl egemen olduğu Kudüs'ü Hittin savaşıly Haçlılardan geri alan ve III. Haçlı seferini etkisiz hale getiren tarihe mal olmuş büyük bir kahramandır. Mehmet Akif’in ifadesiyle "Şarkın en sevgili Sultanı", Fransız tarihçi Champdor'un beyanıyla “İslam’n en saf kahramanı"dır.

Asıl adı "El-Meliku'n-Nâsur, Ebu'l-Muzaffer Selahattin Yusuf bin Necmettin Eyyup bin Şazi el-Eyyubîdir. El-Meliku'n-Nâsır. Yardıma koşan Sultan anlamında olup I. lakabıdır. Ebu'l-Muzaffer = Galip gelenlerin babası anlamında olup künyesidir. Selahattin= Dinin iyileştiricisi anlamında olup II. lakabıdır. Yusuf asıl adıdır. Necmettin Eyyub babasımn lakabı ve adıdı. Şazi (Bazı kaynaklarda Sadi okunmuş) de dedesinin adıdır. El-Eyyub̂̂ ise şöhretidir.

* Prof. Dr., Akdeniz Üniversitesi, Edebiyat Fakültesi, Felsefe Bölümü (E.), Antalya/TÜRKIYYE, ismailyakit@gmail.com 
Selahattin H. 532/M.1138 yılında Selçukluların Tikrit Valisi olan Necmettin Eyyub'un oğlu olarak Tikrit’te dünyaya gelir. Babası Musul Atabeği İmadüddin Zengi ile yakın dostluk kurduğundan aynı yıl Musul'a gider ve Zengi’nin hizmetine girer. Zengi de 1139'da Ba'lebek'i zapt eder ve Necmettin'i buraya vali olarak atar. Kardeşi Esedüddin Şirkuh'u da kumandanları arasına alır. İmadüddin Zengi ölünce oğlu Nurettin Mahmud, Halep ve civarının hükümdarı olur ve Şirkuh'u yanına alır. Necmettin Eyyub da Dımeşk Atabegliğine yani Tuğtekinliler'e bağlanır. Gerek Necmettin ve gerekse Şirkuh iki kardeş, Nurettin'in Haçlllara karşı mücadelesinde ve Dımeşk’i ele geçirmesinde yardım eder. Böylece Nurettin, Necmettin’i Dımeşk valisi, Şirkuh’u da ordu komutanı yapar. İşte Selahattin böyle bir ortamda yetişir, iyi bir eğitim görür, genç yaşında Haçlılara karşı seferlere katılır.

Fatimîler devleti zayıfladı̆̆ından ülke vezirlerle yönetilmekte ve iktidar sık sık el değiştirmekteydi. 1163 yılında Fatimîlerin Veziri Şâver iktidardan uzaklaştırılınca, Nurettin'den yardım ister. Böylece Nurettin’e Mısır'da kriz içinde bulunan Fatimîlere müdahele etme imkanı doğar. Amcası Şirkuh kumandasında 1164-1169 yılları arasında yapılan üç sefere katılan Selahattin iyi bir komutan ve devlet adamı olarak sivrilir. Amcası Şirkuh, 1169'da Kahire'ye girince, Fatimî Halifesi Adid-Lidinillah tarafindan öldürülen Şâver'in yerine vezir olur. Böylece ordusunun büyük bir kısmı Oğuzlar'dan oluştuğu için Mısır’da tekrar Türk, hâkimiyeti devri başlamış olur. İki ay sonra amcası Şirkuh ölünce Selahattin "elMeliku'n-Nâsır" unvanıla vezir olur. Nurettin Zengi'nin komutanı olan Selahattin aynı zamanda Fatimî veziridir. Bu arada Haçlılarla mücadeleye başlar ve çıkan isyanları da önler. Selahattin Mısır'da orduyu yeniden teşkilatlandırır, medreseler açar ve bürokrasiyi kademeli olarak tasfiye eder. Bilahare Nurettin Zengi'nin emri üzerine 1171 'de Fatımîlerin hilafetine son verir' ${ }^{1}$.

Selahattin, Kudüs Haçlı Krallığına karşı pek çok mücadeleye girişir. Ağabeyi Turanşah komutasında Hicaz ve Yemen'e seferler yapar. Nurettin Zengi ölünce oğlu Meliku's-Salih'e bağlı kalır. Çıkan kargaşayı önlemek amacıyla 1174'de Kahire'den Dımeşk'e (=Şam'a) sefer düzenler. 1176'da Musul-Halep kuvvetlerini yenilgiye uğratır. Bu arada sultanlığı Abbasî halifesi tarafından tanınır. Suriye ve Mısır hâkimiyeti onaylanır. Selahattin, 1176'da Haşhaşîleri de bozguna uğratır. Daha sonra Urfa, Harran, Rakka, Habur, Nusaybin ve el-Gezire bölgelerini 
alır. Artuklu Emiri Nurettin bin Muhammed bin Karaarslan'ın isteği üzerine Diyarbakır (Amid)'ı da alır. Daha sonra Halep üzerine yürür ve orayı da alır ve böylece ona Kudüs yolu açılır².

Selahattin bir yandan devleti dağılmaktan kurtarmak ve Ortadoğu'da İslam birliğini sağlamak isterken diğer yandan da Haçlılarla mücadele etmek zorunda kalır. Birkaç kez Haçlılarla çarpışan Selahattin gerçek büyük zaferini 1187'de Hıttin denilen yerde elde eder ve onları büyük bir bozguna uğratır. Haçlı ordusunu imha eder ve pek çok esir ve ganimet ele geçirir. Bunun üzerine Selahattin Akka, Taberiye, Askalan, Nablus, Remle ve Gazze kalelerini zapt eder. Cem'an 52 şehri fetheden Selahattin 02 Ekim 1187'de (27 Recep 583=Miraç olayının yıldönümünde) Kudüs'e girer. Batılılar Kudüs'ün düşmesi üzerine yeni bir Haçlı ordusu düzenlemeye girişirler. İngiltere Kralı I. Richard (Aslan Yürekli Richard) komutasında 1189'da Akka'yı kuşatırlar. 1191'de Akka Haçlıarın eline geçer. Akka ve Yafa sahil şeridini geri alırlar. Selahattin Haçlılarla anlaşma yapar ve kısa bir süre sonra 4 Mart 1193 'te Şam (=Dımeşk)'da vefat eder. Türbesi Şam'dadır³.

\section{Nesebi Hakkındaki Tartışmalar}

Selahattin'in nesebi hakkındaki tartışma onun Kürt, Arap ya da Türk olması temelinde dönmektedir. Bu tartışmalara Ortaasya'da yetişen her ünlü kişiye sahip çıkan İranlılar dâhil olmuyor. Eğer İran'la küçük bir bağlantısı olsaydı, çoktan İranlı yapılmıştı. Selahattin hakkında yapılan araştırmaların birçoğu maalesef bilimsel olmaktan uzak, yakıştırma ve rivayetlere dayanarak yapılan tahmini yorumlar içermektedir. Hele günümüzde silahlı isyana kalkışan ve ayrı bir devlet kurmak hevesinde olan etnikçilerimize göre o tartışmasız Kürt'tür. Çünkü kendilerine yazılı bir tarih, övünecekleri kahramanlar ve büyük simalar gerekmektedir. Kısaca ayrılıkçı bir tarih inşası peşinde olduklarından sahipleniyorlar. Bu sahiplenmede dayandıkları kaynaklar var mı? Varsa ne derece güvenilir? Bunları inceleyeceğiz. Ancak şunu öncelikle söylememiz gerekiyor ki, Selahattin hakkında Kürt, Arap ve Türk diyen kesimlerin her birinin ister orijinal, ister düzmece olsun dayandığı rivayet, kaynak veya belgeleri mevcuttur.

Şunu her şeyden önce belirtelim ki, "Eyyubî ailesinin Kürt kökenli olduğunu ileri süren kaynaklarla, Arap kökenli olduğunu ileri süren kaynakların aynı dönemde yazıldığını göz önünde bulundurmak gerekir”. Bunlar 13. Asır kaynakları olup

Şeşen, a.g.m., s. 337

Şeşen, a.g.m., s. 337 vd. 
Selahattin'in vefatından en az çeyrek asır sonra yazılmış eserlerdir. Mesela İbnü'lEsir’in (öl. 1233); İbn Halikan’ın (öl. 1282), İbn Haldun’un ise ölümü 1406’dır. Bunlardan "İbn Haldun, kendisinden önce yaşamış tarihçilerin eserlerinde bir takım yanlışlıklar bulunduğunu özellikle XII. Asırdan sonra yetişmiş hemen hemen bütün tarihçilerin de benzer hatalara düştüklerini, bunun da bir takım tarihi olaylar hakkında kendilerinden öncekilerin eserlerini sorgulamaksızın kaynak olarak kullanmalarından ve oradaki rivayetleri eserlerine aktarmalarından ileri geldiğini söyler. Onların düştükleri bu hatalar elbette tarih ilminin saygınlığına zarar vermiştir."4

\section{Kürt Olduğunu İddia Edenlerin Görüşleri}

1- Selahattin Eyyubî̀yi Kürt telakki edenlerin en büyük dayanağı İbnü'1-Esîr başta olmak üzere ondan alıntı yapan kaynaklardır. Bazı kaynaklar, Selahaddin’in dedesi Şazi'nin Tiflis yakınlarında Duvin (=Devin=Debil)'de yaşadığını, büyük Kürt aşiretlerinden Hezbânilerin bir kolu olan Ravâdilere mensup olduğunu belirtirler ${ }^{5}$. İbnü'l-Esîr, Necmeddin Eyyub ve kardeşi Şirkuh’un Şazi'nin çocukları olduğunu ve Azerbaycan’ın, Belûdin bölgesinden geldiğini ve Zevadiye (herhalde Revâdiye demek istiyor) kabilesine mensup olduğunu ve bu kabilenin de Kürtlerden olduğunu söylüyor ${ }^{6}$. Gerek İbnü'1-Esîr ve Gerekse İbn Hallikan aileyi Kürt asıllı gösterseler de hiçbir yazılı kaynak göstermemektedirler. Mesela İbn Hallikan bu konuda “... Ehl-i tarih ittifak etmiştir ki..” sözüyle genel ifadeler kullanır. $\mathrm{Bu}$ tarihçilerin kimler olduğunu beyan etmez. Öte yandan İbnü'1-Esîr, meşhur tarihini yıllara ve o yıllarda olan olaylara göre tasnif etmesine rağmen Selahattin'in dedesi ve babasının ve amcasının hangi yılda Belûdin'den veya Duvin/Debil'den ayrıldığını, kaç yaşlarında olduklarını, hangi yılda Zengi’nin hizmetine girdiklerini göstermez. Buradan anlaşllıyor ki, Ahsen Batur'un da dediği gibi "Selahattin ve ailesi hakkındaki bilgiler, belgelere değil, kulaktan dolma rivayetlere dayanarak yazılmışır. ${ }^{97}$

2- "Eyyubî ailesinden bahseden eski kaynaklar İbn Şeddâd'r kaynak olarak kullanırlar ve ailenin Revvâdi(Revâdiye) Kürtleri'nden olduğunu belirtirler. Hâlbuki Selahattin'in çă̆daşı olan İbn Şeddâd da Selahattin hakkında şu kısa bilgiyi verir: "Doğum yeri Tikrit kalesidir. Babası Eyyub b. Şazi Tikrit valisiydi. O, Duvin'de

\footnotetext{
4 İbn Haldun'un bu görüşleri için bkz. Ahmet Arslan, İbn Haldun'un İlim ve Fikir Dünyası, Kültür Bakanlığı yayınları, Ankara 1987, s. 51 vd.

İbn Hallikan, Vefeyâtu'1-Ayan ve Enbâu Ebnâi'z-Zaman, Dâru Sâdır, Beyrut 1972, C. VII, s. 139

İbnu'l- Esir, El-Kâmil fi't-Tarih, Dara'l-Kutubi'l-İlmiyye, Beyrut 2003, C. X, s. 16.

Ahsen Batur, Kürdoloji Yalanlan, Selenge yayınları, İstanbul 2011, s. 382.
} 
doğmuş, sonra Musul'a gelmiş. Oradan da Tiknit'e gitmiştir vb.” İbn Şeddâd Selahaddin’in ve ailesinin etnik kökeni hakkında kesinlikle bilgi vermez, Selahattin'in babasının çöğen (=çevgan) $)^{8}$ oynarken attan düşerek öldüğünü anlatır. Ayrıca, Selahattin’in yaptığı savaşlara ve mücadelelerine hatta başta cömertliği olmak üzere kişiliğiyle ilgili çeşitli yönlerine ağırlık verir'. İbn Şeddâd'ın çağdaşı Selahattin'in etnik mensubiyetinden bahsetmemesi son derece normaldir. Çünkü "o dönemde Türk, Kïrt, Arap etnik adlan değil, ortak kimlik olan Müslïmanlk öncelikli kriterdi”. ${ }^{10}$

3- İbn Hallikan, İbnü'1-Esîr hemen hemen birbirinin kopyası gibi aynı rivayetlere yer vererek Selahadin'in Revadiye Kültlerinden olduğunu yazarlar, ancak İbn Hallikan ailenin kökeni hakkında daha değişik görüşlere de yer verir. Hatta Melikü'1-Muiz İsmail Tuğtekin’in kökenlerinin Ümeyye oğullarına dayandığını iddia etmesi üzerine amcası El-Melikü'l-Âdil'in ona mektup göndererek "gerçek nesebine dön" diye yazdığını söyler. İbn Şeddâd da Selahattin'in böyle bir şeyi reddettiğini ve bunun kesinlikle gerçekle alakasının olmadığını belirtir" ${ }^{11}$ İbn Hallikan bu rivayetini "Ne söylediğini bilen fakih biri bana dedi ki" (Ve kale lî raculun fakîhun'ârifun bimâ yekulu) sözüyle bunu bir belgeye değil, ismini bile vermediği birinin sözüne dayandırır ${ }^{12}$.

4- Selahattin'in Kürtlüğü hakkında bir diğer kaynak 1597'de tamamlanan ve Kürtlerin Soy kütüğü için kaleme alınan Şerefname adlı kitaptır. Bu iddiayı adı geçen kitap, "tarih bilginlerinin ve araştrmacılarn rivayetlerine” bağlamaktadır. Ancak bu bilginlerin ve araştırmacıların kim olduklarını söylemez. Zaten bugüne kadar hiçbir İslam tarihçisi ve bilim adamı bu kitabı teyit etmemiştir. Bu eseri birkaç Batılı yazar ciddiye almış ve onları Kürtlerin siyasi emelleri doğrultusunda yaptıkları yorumlarla desteklemişlerdir. Bunlardan en meşhurları: René Grousset, Claude Gahen ve Minorsky'dir.

5- Bunlardan Grousset, 1192-1193 yllarındaki Şam yöresindeki iç karışıklıkları, Cahen ise, 1187'deki el-Gezîre Türkmenleriyle Kürtler arasındaki otlak kavgalarını "etnik uyuşmazlı" olarak nitelemişlerdir. Hâlbuki bu nevi ihtilaflar

8 Çöğen, At üstünde sopayla yerdeki topa vurarak oynanan bir Türk oyunudur. Farsça çevgan denir. Bugünkü bir nevi polo oyunu gibidir.

9 İbn Şeddâd, En-Nevâdiru's-Sultaniyye ve'l-Mehâsinu'l- Yusufiyye, Siretu Salahaddin, 2. Baskı, Kahire, 1994, s. $32 \mathrm{vd}$.

10 Batur, a.g.e., s. 382

11 Batur, a.g.e., s. 375.

12 İbn Hallikan, a.g.e., C. VII, s. 139 
aynı aşiretin muhtelif oymakları arasında bile tarih boyunca vukua gelmiştir ${ }^{13}$. Minorsky de, şunları söylemektedir:

“Tarihçiler Selahattin Eyyubî’nin babası ve ailesinin Azerbaycan’ın en ucunda bulunan Duvin şehrinden olduğunda anlaşmışlardır. Burası Gürcüler ve Arran yolundadır. Onlar Kürttü ve Revadiye aşiretine mensuptular ki bunlar da büyük Hezbaniye aşiretinin bir koludur. Babası Duvin'de doğmuştur. Dedesi Sadi, Şirkuh ve Necmettin Eyyub adlı iki oğluyla önce Bağdat'a sonra Tikrit'e yerleşmiştir. Dedesi Tikrit’te ölmüş ve türbesi oradadır. Onların soyağacını dikkatlice inceledim ama Sadi’den daha öteye gidemedim"14 demektedir.

Görülüyor ki, Minorsky Selahattin’in babası ve ailesinin Kürt olduğunda tarihçilerin anlaştı̆̆ını söylemektedir. Böyle bir anlaşma söz konusu değildir. Bazı tarihçiler hep birbirinden aktardığından Minorsky onu genelleştirmektedir. Kürdolog Minorsky’nin kaynağı, 16. Asırda Şerefhan Bitlisi tarafindan yazılmış "Şerefname" isimli kitaptır. Minorsky Selahattin'e şecere veremediğine göre demek ki, İbn Halikan'daki ve İbn Haldun'un Mukaddime'sindeki bilgilerden haberi yok. Çünkü 'Soyağactm inceledim ama Sadi'den öteye gidemedim " demektedir.

6-Bugün siyasi Kürtçülerin ellerinde bulunan Şerefname isimli kitap, Bitlisli Şerefhan tarafindan Farsça kaleme alınmış ve 1597'de tamamlanmış devrin Osmanlı Padişahına sunulmuş, belgelerden ziyade rivayetler üzerine yazılmış Kürt toplulukları ve tarihleri üzerine bilgi veren bir kitaptır. İstanbul'da pek çok yazma nüshaları vardır. Şerefname'nin 1860'da Rusça'ya; 1868'de Fransızca'ya 1958-1962 de de Arapça'ya çevirileri yapılmıştır. Türkçe çevirileri; 1971 'de M. Emin Bozarslan tarafindan Arapça'dan ve 2007'de de Fransızca'dan C. Kabadayı tarafindan yapılmıştır. Türkçe çevirileri, bir başka dile yapılan çevirilerden yapılmıştır. Örnek verecek olursak; C. Kabadayı'nın çevirisinde F. Bernard Charmoy'un Fransızca çevirisi esasa alınmıştır. Onun notlarına ek birçok notların ilave edildiği görülmüş̧ür. Şöyle ki toplam 5 ciltte yayımlanan bu tercüme cem'an 2000 sayfayı geçmektedir. Bunun sadece 500 sayfası Şerefhan'a aittir. Bu açıklamalarla kitap, adeta ideolojik bir Kürt tarihine dönüştürülmek istenmiştir. Kaldı ki, Şerefhan, kendisi Osmanlıya bağlı, bağımsızlık talebi olmayan hatta hiç de Kürtçü olmadığı anlaşılan biridir. Çevirinin orijinalinden değil de Batı

13 Şeşen, a.g.e., s. 11

14 Vladimir Minorsky, "The Prehistory of Saladin" in Caucasian History, Cambridge University Press, Usa, 1957 , s. 125 
dillerindeki tercümelerinden yapılmasının sebebi acaba nedir? Türkiye'de bir Kürt devleti kurulmasını isteyen Batılıların kendi dillerine yaptıkları tercümede ne derece orijinaline sadık kaldıkları veya tahrifatta bulunup bulunmadıkları doğrusu merak konusudur. Türkçe tercüme de "Kürt ulusunun tarihi” alt başlı̆̆ıyla yayımlanmıştır. Ulus/millet kavramının günümüzdeki anlamda kullanılmadığı bir dönemde yazılan Şerefname'de böyle bir ifade yoktur. Orada "Kürtlerin tarihi" ibaresi vardır. Ulus karşılığı kullanılan kelime "taife " kelimesidir. Taife Arapçada hatta Farsçada bile kabile, bölük, grup anlamına gelir. Şerefname, taife sözcügünü grup, bölük, kabile aşiret anlamında kullanmıştır ${ }^{15}$.

\section{Arap Olduğunu İddia Edenlerin Görüşleri}

1- Selahadin’in Arap olduğunu iddia eden kaynakların başında İbn Vâsıl (öl: 1298) gelir. O, Müferricü'l-Kulûb fi Ahbâri Benî Eyyûb adlı eserinde; Musullu tarihçi İbnü'l-Esîr'in, Eyyubîlerin aslının Hezbanilerin aşiretinden olan Ravvâdi Kürtlerine dayandırmasına karşı çıkar ve der ki: "Eyyub oğullarından bir hükümdar Kürtlerden olduklarını reddetti ve şöyle dedi: 'Biz, Arabız, Kürtlerin yanma konduk ve onlardan kız aldık'. ${ }^{16}$

2- Eyyubîlerin Kürt olmadığını belirten bir diğer kaynak Halepli İbn Ebu Tayyip'tir. O şöyle yazmaktadır: "Şu Emir Necmettin Eyyub b. Şazi'(nin).. nesebi konusunda babasi Şazi'den ötesi bilinmez. Seyfuilislam'n oğlu Yemen'e kral olduktan sonra Emevilerden geldiklerini iddia etti. Fakat Eyyub ailesi bunun yalan olduğunu söylediler ve Şazi'den önceki atalarm bilmediklerini belirttiler. Bunu bana Melikü’n-Nâsır da bu şekilde bildirmişti"'17 Melikü'n-Nâsır'dan kasıt Selahattin Eyyubî'nin kendisi olduğuna göre, demek ki o bile dedesinden öte isnat edilen şecereleri kabul etmemektedir.

3- Eyyubîler sülalesinden Hasan b. Davut el-Eyyubî Fevâidü'l-Celiyye fi'lFerâidi'n-Nâstriyye adlı eserinde dedelerinin soyuyla ilgili söylenenlere açıklık getirerek, onların Kürt olmadıklarını, aksine onların yaşadıkları yere konduklarını, bu yüzden onlardan biriymiş gibi zannedildiklerini kesin bir dille belirtmiş ve şöyle demiştir: "Sülalemizin büyüklerinden yetişebildiklerimden hiç kimsenin bizim Kürtlerden olduğumuzu söylediğini görmedim". Hasan b. Davut bunu söyler ama akabinde Hasan b. Garib'in Emevilere kadar ulaşan şeceresini kabullenir ${ }^{18}$.

15 Krş. www. tarihtendersler.com. erişim tar. 25.01.2017

16 İbn Vâsıl, Muferricu'l-Kulûb fì Ahbâri Beni Eyyûb, Kahire, 1954, C. I, s. 6; Krş. Batur, a.gee., s. 377.

17 Bkz. Fevâidii'1-Celiyye..'den naklen tere. A. Batur, a.g.e., s. 379.

18 Bkz. İbn Ebu Tayyib'den naklen, A. Batur, a.ge.e, s. 379. 
4- Selahattin Eyyubî’yi Arap kökenli gösteren bir diğer kaynak Ünlü bilgin İbn Haldun'un Mukaddime'sidir. İbn Haldun bu eserinde, Selahattin'in büyük atalarının Yemen'in Himyeri vilayetine mensup Araplardan olduğunu ve aşiretinin Himyeri bölgesini yüzyllarca yönetmiş Devs hanedanına akraba olduğunu da belirtir. Sonra bunların Azerbaycan bölgesine geldiğini ve oradan da tekrar Kuzey Irak'a yerleştiklerini kaydeder. Aynı İbn Haldun Eyyubîler ve Memluklular için "Türrk Devleti" tabirini kullanır ${ }^{19}$. Buradan anlaşılan Türkleşmiş bir Arap olabileceğidir.

5- İbn Haldun'un yanı sıra Zeki Velidi Togan da, bazı İslam Tarihi kaynaklarına, özellikle Aksarayî’nin eserine dayanarak Selahaddin Eyyubî’ nin soyunu, 758 yılında Basra'dan Azerbaycan'a sürgün edilen (nakledilen veya göçen), Yemen Araplarından Ravvad bin el-Müsenna el-Ezdi'nin soyuna dayandırır. Bu bağlamda naklettiği rivayete göre; bu aile Azerbaycan'daki Hezbaniyye Kürtleriyle karışmış, daha sonra da Kuzey Irak'a dönerek Selçukluların ve Zengilerin himayesine girmişlerdir. Buradan hareketle o, Eyyubîler’in önce Kürtleşmiş sonra da Türkleşmiş bir Arap sülalesinden olduğunu yazar ${ }^{20}$.

6- Bazı Arapça kaynaklarda, Eyyubî ailesinin soy kütüğüyle ilgili kayıtlara ve şecerelere rastlanır. Her ne kadar Eyyubîler, Şazi'den öteye dedelerini bilmeseler de onlara Emevilere kadar, Hatta Hz. Âdem'e kadar uzanan şecereler de izafe etmektedir. Şecere uydurmak, uydurma hadislerde olduğu gibi eski bir Arap geleneğidir. Bu şecerelere kendini kaptıran Seyfülislam Tuğtekin’in oğlu Ebu'lFida İsmail, Yemen'de kendisi için el-Mehdi unvanı alır, halifelik elbisesi giyer ve soylarının Emevilere dayandı̆̆ım iddia eder. Bunun üzerine amcası El-Melikü’lAdil Seyfeddin Ebubekr b. Eyyub'un: "Bu gibi gülïnç şeyleri brrak asıl nesebine dön" diye mektup yazdı̆̆ı, etrafindakilere de "İsmail yalan söylemiş, biz kesinlikle Emevilerden değiliz.” Dediği kaynaklarda zikredilirr ${ }^{21}$. Ancak, asıl neseplerini belirtmez ${ }^{22}$.

7- Yemen'den Basra'ya, Basra'dan Azerbaycan'a oradan da tekrar Kuzey Irak'a göç hikâyesi, bilimsel anlamda pek itibar edilecek bir olay değildir. Çünkü bu göçün sosyal ve siyasi sebepleri ortaya çıkarılamamıştır. Öte yandan yüzlerce yll geriye giderek aile sicilini tespit etmek de pek mümkün değildir.

\footnotetext{
19 İbn Haldun, Mukadime, çev., Zakir Kadiri Ugan, Şark-İslâm Klasikleri, Milli Eğitim Basımevi, İstanbul 1986, C. II, s. 622 vd. Mütercimin notu).

20 Zeki Velidi Togan, Umumi Türk Tarihine Giriş, Enderun Kitabevi, 3. Baskı, İstanbul 1983, s. 179.

${ }_{21}$ İbn Hallikan, a.g.e., C. VII, s. 140; Makrizî, Kìtâbu's-Sulûk li Ma'rifeti Düveli'l-Mulûk, Nşr. Muhamed Mustafa Ziyade, Kahire 1956, s. 42; Hanbeli, Şifâu'l-Kulûb fi Menâkıbı Beni Eyyub, Tahkik: Nazım Reşid, Irak 1978 s. 174.

22 Batur, a.g.e., s. 386.
} 
8- Ancak Emeviler'in zulmünden, Ehl-i Beyt'in Horasan, Harezm Maveraünnehr bölgelerine göç ettiği biliniyor. Hatta Arap fetihleri dolayısıyla bazı Arap kabilelerinin Kafkaslara, Horasan'a yerleştikleri, oralarda Arapça ve Farsça konuştukları tarihen sabit olan olaylardır. Ünlü gezgin ve coğrafyacı İstahrî̀ye göre; Azerbaycan, Ermenistan ve Aran'da ${ }^{23}$ Arapça ve Farsça konuşulduğunu Düvin/Devin/Debil ve Barda civarında ve çevresinde Ermenice ve Arran (=Aran) dili konuşulur şeklindeki kaydı önemlidir² ${ }^{24}$ Aran dilini, Azeri araştırmacılar, TürkAlban (=Arnavut) dili olarak tespit etmişlerdir. Nitekim:

"Aran dili, tarihi Aran coğrafyasında konuşulan dildir. Aran dilinin eski Udi dili olduğunu iddia etmek için bazı sebepler vardır. Birçok uzmanın Aran dili ile Türk-Alban dilini kastettikleri belirtilmektedir. Uzmanlar bu fikirlerini Arap araştırmacılarının IX-X. Yüzyıllarda bile Berde etrafinda Aran dilinin yerli ahali tarafindan korunması ile açıklıyorlar. Bu devirde ise Berdelilerin Türkler (bugünkü Azerbaycan Türklerinin ecdadları) olması gerçeği şüphe götürmüyor". ${ }^{25}$

Görülüyor ki, Selahattin’in ailesinin geldiği bölgede konuşulan diller, Arapça, Farsça, Ermenice ve Aran (Türkçe-Alban) dilleri şeklinde sıralanabilir. İstahrî niye Kürtçe demiyor? Herhalde öyle bir dil konuşulmuyordu.

\section{Türk Olduğunu İddia Edenlerin Görüşleri}

1- Konuyu biraz önceye götürelim: Selçuklu Sultanının hizmetinde bulunan Atabeg'lerden Zengi, Bağdat Halifesinin askerlerini mağlup ederek ün kazanmış bir komutandır. Mezopotamya ve Suriye'de bir devlet kurar ve akabinde 1144 yılında o zaman Haçlıların elinde bulunan Halep Kontluğunu ele geçirir. Zengi, iki sene sonra vefat edince yerine oğlu Nurettin Zengi geçer. O vakitler Mısır'da Şii Fatimî devleti vardır ve eski gücünde olmadığından Haçlıların tehdidi altındadır. Fatimî iktidarının Başveziri olan Şâver, Nurettin Zengi'den yardım ister. Nurettin Zengi, Fatimî Halifesine yazdığı cevabi mektupta, kendisini değil ama yardıma Türkleri göndereceğini, onlara güvendiğini ve Frankların mızraklarına karşı koyabilecek gücün Türklerin oklarında olduğunu açıkça belirtir. Türklerden teşekkül etmiş bu ordunun komutanı Şirkuh'tur. Şirkuh (anlamı dağ arslanı demektir),

23 Kaynaklarda geçen "Erran" 1 Ermenistan'ın başkenti Erivan olarak gösterenler de vardır. Bize göre Arran=Aran'dır. Aran da Azerbaycan'da bir bölge adıdır.

24 İstahrî, Mesâliku’l-Memâlik, M.J. de Goeje neşri, L.- Batavorum 1927, s. 6; Batur, a.g.e., s. 382

25 Qiyaseddin Qeybullahayev, Azerbaycan Türklerinin Tessekkül Tarihinden, Bakı 1993, s. 26. 
Selahattin'in öz amcasıdır ve kendisi de amcasıyla beraber ordunun başındadır. Uzun muharebelerden sonra Fatimî Şâver ölür yerine Şirkuh geçer, sonra Şirkuh da ölünce yerine Selahattin geçer ve böylece Mısır'da Eyyubî iktidarı başlamış olur. Şu halde Zengi'nin kendisinden yardım isteyen Şâver'a yazdığı mektupta "Türklerden bir ordu göndereceğini" söylemesi ve Selahattin'in amcasının emrinde Selahattin'i de göndermesi onun Türk olduğunun delilidir. Nitekim Selahattin devrindeki tarihçiler Mısır’n, Yemen’in, Trablusgarp’ın ele geçirilmesini bir Oğuz hareketi olarak görürler. Amcası Esedüddin Şirkuh kumandasında Mısır’a giden 7000 civarındaki süvariden 6000'den fazlasının Türk olduğunu kaydederler ${ }^{26}$.

2- Bütün tarihî kaynaklarda Eyyubî devleti için Arapça "ed-Devletü'l-etrâk" (Türklerin devleti) tabiri kullanılmaktadır. Sözgelimi o dönemin tarihçilerinden İbn Attar : "Fatimîlerden sonra Misır'da saltanatun Türklerin eline geçtiğini" yazar. Eğer kurucuları Türk olmasaydı, ünlü tarihçi niye böyle bir tabir kullansın? Hatta Eyyubîlerden sonra kurulan Memluklular için de bu tabir kullanıla gelmiştir. Devletin ismi, onu kuranlarla alakalıdır. "Eyyubîleri bir Kürt devleti gibi gösterenler Türklere muhalif olan veya mutaassip Kürt olan sonraki birkaç tarihçi ve bugün doğu milletlerini bölmek isteyen batılı bazı tarihçilerdir”27.

3- Selahattin’in kurduğu Eyyubî devletinin dili Türkçedir. Kaldı ki Mısır'da halk Arapça konuşmaktadır. Türk olmayan bir sultanın kurduğu devletin dili niye Türkçe olsun ki.? Ahmet Ateş’in araştırmalarına göre, Selahattin’in sarayında yani Eyyubî sarayında Türkçe konuşulurdu ${ }^{28}$. Yapılan araştırmalara göre; hemen hemen bütün belgelerde Selahattin'in kurduğu Eyyubîler devletinde günlük hayatta, askerlikte, diplomaside, sanat ve edebiyatta bütün belgelerde Türklük ve Türk gelenekleri ve motiflerinin kullanıldığı açık açı görülmektedir.

4- O dönemde yaşamış şairler, şïrlerinde Selahattin’in ve ordusunun Türk olduğunu, onlarla İslam'ın güçlü ve saygın hale geldiğini anlatır. Bunlardan bazı örnekler verelim: Arap Şairi İbn Sena el-Mülk, Halep’in zaptı üzerine Selahattin’e sunduğu kasidede: “Arap milleti Türklerin devletiyle yükseldi, Ehl-i Salib'in davast Eyyupoğlu tarafindan perişan edildi" mısralarıyla başlar. Ayrıca, Şair Arkale, Selahattin'in amcası Esedüddin Şirkuh'un H.562/ M. 1166-1167'de Misır'a yürüdüğünde durumu anlatan şiirine şöyle başlıyor: "Ekûlu ve'l-Etrâk kad ezma'at Mısra ilâ harbi'l-E'ârîb.."

\footnotetext{
Şeşen, Salahaddin Eyyubî ve Devlet, Çă̆ Yayınları, İstanbul 1987, s. 10.

Şeşen, a.g.e., s. 10-11.

28 Ali Rıza Özdemir, Kürtler ve Türklük, Kripto yayınları, Ankara 2009, s. 271.
} 
(Ben diyorum ki: Türkler Misır üzerine yürüyerek Araplarla savaşmaya kesin kararlddrlar...) ${ }^{29}$.

5- Kadı Ebu Mehâsin, ikinci defa Mısır'dan başarısız dönüşünün üzerine halk arasında tekrar geleceği şayiası üzerine vezir Şâver korkarak Franklarla haberleşmeye giriştiğini beyan ederek Arapça: "Hatta beleğa Şâver zalike ve dahalehu'l-havfe ala bilâdi mine'l-etrâk” (Bu haber Şâver'e ulaşınca Türkler'in beldelerine istilasindan korkuya kapildi) demektedir ${ }^{30}$.

6- Selahattin'in kendisini Türk hissettiğine dair bir örnek: Şair Saadet, Selahattin Mısır'a sahip olduğunda Mısır'a gelmiş ve Selahattin’i bir kasideyle övmüştür. Selahattin de ona bin dinar bağışlamıştır. O, Selahattin'in Misır'dan hareket ederek, Frankların elinde bulunan Gazze' yi ele geçirdiğini ve zaferle döndügünü anlatırken de şöyle demektedir: "Selahattin öyle bir yiğit $k i$, sïvariler ve piyadeleriyle Gazze"nin üzerine yürüdüğ̈̈nde" diye başlayan şïrinde devamla " $O$, Gazze'nin etrafinda Türklerden ibaret olan askerleriyle onlar bozgun ve tahribe uğratth. Türkler, Nubeliler gibi ahmak ve aşağı olmadiklan gibi Kipti de değildiler" diyerek Selahattin ve ordusunun Türk olduğuna vurgu yapıyor ${ }^{31}$.

7- Katip İmad (İmadaddin İsfehanî) Sultan Selahattin’in katına gelen elçileri şöyle anlatıyor: "Annesi tarafindan kardeşinin oğhu olan Rükneddin Tuğrul bin Arslan bin Tuğrul bin Muhammed bin Melikşah’in elçisi Sultan’in katına geldi" diyerek Sultanın annesinin Selçukîlerden olduğunu vurgulamaktadır. Şehabeddin Muhammed bin Tokuş, Şam Selçukîleri'nin evlatlarından olduğu için o da Selahattin'in dayısıdır. Fark birinin nesep cihetinden diğerlerinden daha yakın olmasindadır ${ }^{32}$.

8- Ugan, açıklayıcı notlarında: “...Sultan Selahattin'in Türklüğ̈ alçaltan seylere de tahammülü yoktu... “ diyerek Katip İmad'nn Haride'sinden örnekler verir. Şöyle ki. Sultan, Hamıs'n dışarısında ordugâhını kurduğu esnada yanına şair Mühezzeb bin Es'ad gelir. Sultanı överek bir kaside söyler. Yanında bulunan Kadı Fazıl, Sultana: "Şiir Türkler nezdinde daima metruk kalmıştır diyen şair işte bu şairdir" dediği zaman, Sultan şairin sözünü yalanlamak ve yapıldığını ispatlamak için onu özellikle ödüllendirir. Ona hil'at ve tarla/arazi bağışlar. Sultan bu davranışıyla, Türklerin indinde şïrin metruk olmadığını ispat eder. Zira Şair

29 Merhum Kadiri Ugan'in bu notları için bkz. İbn Haldun a.g.e., C. II, s. 625.

30 İbn Haldun, a.g.e., C. II, s. 625 vd.

31 Bkz. İbn Haldun, a.g.e., C. II, s. 625 vd.

32 İbn Haldun, a.g.e., C. II, s. 627. 
Mühezzeb, Mısır Fatimî veziri Salih bin Zürayük'ü övdüğü kasidesinde Türklere "İhsan ve bağrşlarm ümit ederek Türkleri mi öveyim? Hâlbuki şïr onlar nezdinde daima metruk kalmıstır" misralarıyla dokundurmuştu. Buradan anlaşılıyor ki, Ugan'in da dediği gibi "Selahattin kendini Türk sayardı, (yani kendisini Türk hissederdi.) Türklüğe dokunan şeylere tahammülü yoktu"33.

9- Selahattin'in kardeşlerinin isimleri şöyledir: Muhammed Ebu Bekir, Şemsuddevle Turanşah, Seyfülislam Tuğtekin ve Tâcülmülük Börü (Kurt)'dür. İsimlerin önüne bir lakap almak o zamanlar İslami bir gelenekti. Dolayısıyla Turanşah’ın lakabı Şemsuddevle (=Devlet güneşi), Tuğtekin’in lakabı Seyfülislam (= İslam'ın kılıcı), Börü'nün lakabı ise Tacülmüluk (Ülkelerin tacı)'dır. Şu halde asıl isimleri: Turanşah Tuğtekin ve Börü'dür. Bu isimlerin tamamı Türk isimleridir. Türk olmayan birisi çocuklarına niye bu isimleri koysun ki... bu isimler "Şerefname"de bile aynen kayıtlıdır.

10- Selahaddin'in annesi, Amine Hatun bin Onur, Şehabeddin Mahmut bin Tokuş'un kardeşidir. Türk'tür. Selahattin'in kız kardeşi Rabia Hatun, önce Saadettin Mesut bin Onur (Üner), sonra da Muzafferüddin Gökbörü ile evlenmiştir. Her ikisi de Türk’tür. Gökbörü Türkçede Bozkurt demektir. Ağabeyi Şahinşah’ın eşinin adı Kutlukız Hatun idi. (Şeşen, 1987: s. 10). Selahattin'in kendi kızının adı Munise Hatun'dur ${ }^{34}$. Görüldüğü gibi, Selahattin’in hanımı, annesi, yengesi, kız kardeşinin ve kızının isimlerinin yanında "Hatun" tabiri yer almaktadır. Hanımların isimlerinin yanına Hatun(=katun) sözü ilave edilmesi Türklere has bir özelliktir. Bu eski bir Türk geleneğidir. Hatun sözcüğünün aslı Öztürkçede "katun" dur. Kadın sözcüğ̈̈ buradan gelir"

11- Selahattin'in danışmanlarından Üsame bin Munkız'in hatıralarını içeren "Kitabü'l-ltibar" isimli bir kitap Türkçe'ye tercüme edilmiştir. Yazarın asıl adı şu şekildedir: Müeyyedü’t-Devlet Ebu'l-Haris Üsame bin Mürşid bin Ali bin Munkız". Kısaca “Íbn Munkız” diye tanınır. İbn Munkız, Malazgirt Savaşı'ndan 24 yıl sonra, Haçlıların Kudüs'ü işgalinden 4 yıl önce Hama civarında Şayzer'de doğmuş, şair, edip bir tarihçidir ve 93 yıllık ömründe 20'den fazla eser yazmıştır. Selahattin Eyyubî ile birçok savaşlara katılmıştır. Yukarıda adı geçen kitabın 201. Sayfasında şöyle bir anısını nakleder:

33 İbn Haldun, a.ge., C. II, s. 628-629.

34 Ayşe Dudu Kuşçu, Eyyubî Devleti Teşkilatr, Türk Tarih Kurumu, Ankara, 2013, s. 41.

35 Bkz. Kaşgarl, Mahmut, Divanu Ligati’t-Türk, Tercüme: Besim Atalay, TDK yayınları, 3. Bask1, Ankara 1992, C. I, s. 138, 376, 410, C. II, 20, 240; Hüseyin Namık Orkun, Eski Türk Yaztlan, Ankara 1994, s. 34, 183. 
"Bu arada Selahattin, buradaki kritik durumumuzu bildirmek üzere Atabek'e bir atlı gönderdi. Sonra, hızla bize doğru ilerleyen on kadar atlı gördük Arkalarındaki ordu da sürekli hareket halindeydi. Geldiklerinde, Atabeg'in komutasındaki öncüler olduğunu anladık Ordu da arkalarından gelecekti. Atabek,'Ey Musa, mahvolmak için mi otuz atlıyla Şam kapısına kadar geldin! Ne acelen vardı' diye Selahattin’i eleştirdi. Karşılıklı atıştılar. İkisi de Türkçe konuşuyordu. Bu yüzden söylediklerini anlayamadım." ${ }^{36}$

Bu konuda değerli dostum merhum Necdet Sevinç’in şu sözlerine katılmamak elde değil: "Farsçanın siyaset, A rap̧̧a'nın bilim, eğitim ve din alanında tartışılmaz bir üstünlük kurduğu ve Türk dilini ögreten bir kurumun dahi bulunmadiğı böyle bir devirde Selahattin Eyyub̂̂nin Türkçe konuşması, onun öz be öz Türk olduğunu gösteren en büyük delildir."’37

12- Selahattin'in yönettiği devlet Eyyubîler devleti; Selçuklu, ve Selçukluların bünyesinden temayüz etmiş olan Zengiler'in halefi ve kendilerinden sonra bölgede hüküm sürecek olan Memluklar'nn da selefidir. Zira devlet teşkilatı değişmemiş, millet değişmemiş sadece hanedanlar değişmiştir. Her üç devletin bayrağı da açık sarı zemin üzerine doru kartaldır. Her üç devletin askeri ve siyasi kadroları da aynıdır. Bu konuda Eyyubîler uzmanı değerli dostum Ramazan Şeşen’in de belirttiği gibi, devlet ve ordu teşkilatları Türk devletlerinde görülen devlet ve ordu teşkilatlarının aynıdır ${ }^{38}$. Hatta İbn Haldun, meşhur Mukaddime'sinde Eyyubîler ve Memluklar devletinin bir tek Türk devleti olduğunu kabul eder. Hatta, Selahattin devrinden beri Türklerin devletinde ilmin ve ilim adamlarının teşvik ve himaye gördügünü, Kahire’nin dünyanın büyük ilim merkezlerinden biri haline geldiğini belirtir ${ }^{39}$. Bütün bunlara rağmen, birilerinin kalkıp da Eyyubî devleti için "Kürt devleti" demelerinin bilimsel ve tarihi hiçbir mesnedi yoktur. Ayrılıkçı bir tarih inşa etmek isteyenlerin mesnedi olmayan iddialarıdır.

13- Tarihi gerçeklere baktığımız zaman görürüz ki, Selahattin’in kurduğu devletin coğrafyası Mısır ve çevresidir. Burada halkın büyük bir çoğunluğu Arap’tır. Ordu ve idari zümre ise çoğunluğu Türklerden oluşmaktadır. Zaten daha önce orada hep Türk hanedanlıkları vardı. Mesela Tolunoğulları (868-905) yılları arasında Mısır'da hüküm sürdüler. Yine Ihşidi hanedanlığı olarak bilinen ve Türk komutan

36 İbn Munkız, Kìtâbu’l-I'tibâr, Tercüme: Yusuf Ziya Cömert, sese Yayınları, İstanbul 1992, s. 201.

37 Necdet Sevinç, "Selahaddin Eyyubî Türk'tür", Yeniçağ, 5-12 Ekim, İstanbul 2004.

38 Şeşen, a.g.e., s. 10.

39 Ayrica bkz. Abdulmacid Turkî, "De Quelques Affinités Culturelles Tuniso-Turques, Estrato dela Rivista" Alifba, Gennaio-Giugno1985, s. 4 
Toğaçoğlu Muhammet Ebu Bekir tarafindan kurulan hakimiyet (935-969) yılları arasında orada hüküm sürmüştür. Her iki hanedanlık Abbasilerin Türklere askeri alanda yer vermeleri sonucu ortaya çıkmıştır. Ihşidileri de şii Fatimîler 969'da yıkmışlar ama Fatimîleri de Türk komutan Selahaddin yıkmış ve Eyyubîleri kurmuştur. Onları da yıkan Türk Memluk Devletini kuran İzettin Aybeg'dir. Bu zincirleme gelişme Mısır'da ahali her ne kadar Arap olsa da ordunun ve hanedanın hep Türkler'de kaldığının göstergesidir.

14- Türk devletlerinde en sık görülen özelliklerden biri, hiç şüphesiz “devlet, hanedanın ortak mülküdür" anlayışıdır. Bu sebeple Türk hükümdarlarının vefatından sonra ülke oğulları arasında pay edile gelmiştir. Bunları bazen hükümdarların kendileri de pay etmiştir. Dolayısıyla Selahattin de bu Türk geleneğine sadık kalarak, hayattayken büyük bir Türk-İslam devleti olan Eyyubî devleti hanedanlığını oğulları arasında paylaştırmıştır.

15- Öte yandan başkalarının "Arap kültürü” nün baskın oluşundan dolayı devleti Arap göstermelerinin de hiçbir mantığı yoktur. Çünkü kültürler arası sürekli bir alışveriş ve etkiler tarih boyunca söz konusu olagelmiştir. Roma imparatorluğuna Yunan kültürü hâkim olmuş, Orta Asya Türk devletlerinden Gaznelilere, Selçuklulara Fars kültürü hâkim olmuş, hatta devletin resmi dili bile Selçuklularda Farsça olmuştur. Tıpkı bunun gibi, Zengi, Eyyubî ve Memluklarda Müslüman olduklarından dolayı elbette Arap kültürünün izleri de olacaktır. Ancak yukarıda da belirttiğimiz gibi Selahattin üzerindeki etkin kültür, daha ziyade Türkİslam kültürüdür.

\section{Sonuç}

Selahattin, ününü duyduğu ve eserlerini okuduğu Musullu yazar İbn Şeddâd'ı yanına çă̆ırır ve onu yakın sırdaşı ve danışmanı yapar. İbn Şeddâd da ölene kadar onun yanında kalır, savaş ve anılarını yazar. Ayrıca Selahattin hakkında da müstakil bir kitap kaleme alır. Onu en yakından tanıyan İbn Şeddâd Selahattin’in Kürt ve Arap olduğundan hiç bahsetmediği gibi, onu herhangi bir soya veya şecereye de dayandırmaz. Ancak diğer kaynaklar onu kendisinden sonra bir takım etnik unsurlara bağlamaya çalışmışlardır. Biz bu çalışmamızda onun biyolojik olarak bir ırka aidiyetini belirtmek istemiyoruz. Zaten böyle bir şey mümkün de değildir. Burada asıl olan Selahattin’in, babasının ve amcasının kısaca Eyyubi

ailesinin Türk-İslam kültür ve geleneklerine göre yetiştiği, ordusunun ekseriyetinin Türklerden oluştuğu ve kurduğu devletin büyük bir Türk devleti olduğu, zamanında 
yaşamış şairlerin yüzüne karşı okuduğu şiirlerde Türklügünü vurgulamış olması ve bundan dolayı kendilerini ödüllendirmiş bulunması, Türklüğü alçaltan hiçbir şeye tahammül edememesi, en azından kendini Türk hissettiğinin açık ve bariz kanıtıdır. Farz edelim ki Selahattin etnik olarak Türk olmasa bile o, safkan Türküm diyenlerden çok daha Türk'tü. İnsanı insan yapan ve onun şahsiyetine şekil veren ırkı değil, aldığı terbiye ve içinde yaşadığı kültürdür. O Türk-İslam kültürü içinde kimliğini bulmuş ve Müslümanları Haçlıların boyunduruğundan kurtarmış muzaffer bir kumandandır. Onun Kürtlüğüne ve Araplığına dair ileri sürülen etnik iddialara bakıldığında yukarıda belirttiğimiz gibi, vefatından yıllar sonra belgelere göre değil de rivayetlere göre yazılmış ve birbirinden kopyalanarak gelen kaynaklarda görmekteyiz. Bunlara dayanarak isminin yanına el-Kürdî sıfatı yakıştırmak, bu büyük İslam kumandanını Türk milleti ve kültüründen ayrı tutmak isteyen art niyetli batılı bazı tarihçilerin ve bölücülerin bir tuzağından başka bir şey değildir.

\section{KAYNAKLAR}

Arslan, Ahmet, Ibn Haldun'un Ilim ve Fikir Dünyası, Kültür Bakanlığı Yayınları, Ankara 1987.

Batur, Ahsen, Kürdoloji Yalanlar, Selenge Yayınlan, İstanbul 2011.

Hanbeli, Ahmet b. İbrahim, Şifâu’l-Kulûb fi Menâkıbı Beni Eyyub, Tahkik: Nâzım Reşid, Irak 1978.

İbn Haldun, Veliyuddin Ebu Zeyd Abdurrahman Mukaddime, Çev. Zakir Kadiri Ugan, Şark-İslam Klasikleri, Milli Eğitim Basımevi, İstanbul 1986.

İbn Hallikan, Ebu'l-Abbas Şemseddin Ahmed, Vefeyâtu'l-Ayan ve Enbâu Ebnâi'z-Zaman, Dara Sâdır, Beyrut 1972.

İbn Khaldun, Valiyouddin, Discours Sur l'Histoire Üniverselle (Al-Muqaddima),(I-III), Traduction nouvelle, preface et Notes par Vincent Monteil, Sindbad, Paris 19671968.

İbn Munkız, Usâme b. Munkız, Kitabu'l-I'tibâr, Tercüme: Yusuf Ziya Cömert, (Philippe K. Hitti’nin İngilizce Tercümesinden) Ses Yayınlan, İstanbul 1992.

İbn Şeddâd, Bahaddin, En-Nevâdiru's-Sultaniyye vel-Mehâsinu'l-Yusufiyye, Siretu Salahaddin, 2 Baskı, Kahire 1994.

İbn Vâsıl, Cemaleddin Muhammed, Muferricu'l-Kulûb fi Ahbâri Beni Eyyub, (I-V), Kahire, 1954 
İbnü'l-Esîr, İzzeddin Ebu'l-Hasan, El-Kâmil fi't-Tarih, (I-XI), Daru'l-Kutubi'l-İlmiyye, Beyrouth 2003.

İstahrî, Ebu İshak İbrahim, Mesâliku’l-Memâlik, MJ. de Goeje neşri, L.-Batavorum 1927.

Kaşgarlı, Mahmut, Divanu Lügati't-Türk, Tercüme: Besim Atalay, TDK, Yay., 3. Bask1, Ankara 1992.

Kuşçu, Ayşe Dudu, Eyyubî Devleti Teşkilatı, Türk Tarih Kurumu, Ankara 2013.

Makrizî, Takiyüddin Ahmet, Kitâbu's-Sulûk li-Ma'rifeti Düveli'l- Mulük, Nşr: Muhammet Mustafa Ziyâde, Kahire 1956.

Minorsky, Vladimir, The Prehistory of Saladin, Studies in Caucasian History, Cambridge University Press, 1957.

Orkun, H. Namı, Eski Türk Yazztlar, Ankara, 1994.

Özdemir, Ali Rıza, Kürtler ve Türklïk, Kripto Yay., Ankara, 2009.

QeybuUahayev, Qiyaseddin, Azerbaycan Türklerinin Teşekkül Tarihinden, Bakı, 1994.

Sevinç, Necdet, Selahaddin Eyyubî Türk'tür, Yeniçă̆, 5-12 Ekim, 2004.

Şeşen, Ramazan, Selahaddin Eyyûbi, Maddesi, Diyanet İslam Ansiklopedisi, C. 36 /337-340, İstanbul 2009.

Şeşen, Ramazan, Salahaddin Eyyûbî ve Devlet, Çağ Yayınları, İstanbul 1987.

Togan, Zeki, Velidi, Umumi Türk Tarihine Giriş, Enderun Kitabevi, 3. Baskı, İstanbul 1983.

Turki, Abdulmacid, De Quelques Affinités Culturelles Tuniso-Turques, Estrato Delia Rivista "Alifba", 2, 4, Gennaio-Giugno 1985.

www. tarihtendersler.com. erişim tar. 25.01.2017 Kürt Tarihi Nasıl Uyduruldu? 